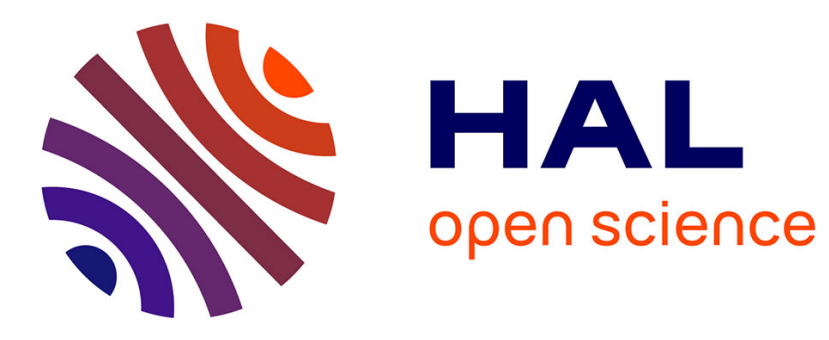

\title{
Database of pleistocene periglacial featuresin France: description of the online version
}

Eric Andrieux, Pascal Bertran, Pierre Antoine, Laurent Deschodt, Arnaud

Lenoble, Sylvie Coutard, Aurelie Ajas, Quentin Borderie, Jean-Pierre

Coutard, Francois Didierjean, et al.

\section{To cite this version:}

Eric Andrieux, Pascal Bertran, Pierre Antoine, Laurent Deschodt, Arnaud Lenoble, et al.. Database of pleistocene periglacial featuresin France: description of the online version. Quaternaire, 2016, vol. 27/4, pp.329-339. 10.4000/quaternaire.7717 . hal-02346049

\section{HAL Id: hal-02346049 \\ https://hal.science/hal-02346049}

Submitted on 4 Nov 2019

HAL is a multi-disciplinary open access archive for the deposit and dissemination of scientific research documents, whether they are published or not. The documents may come from teaching and research institutions in France or abroad, or from public or private research centers.
L'archive ouverte pluridisciplinaire HAL, est destinée au dépôt et à la diffusion de documents scientifiques de niveau recherche, publiés ou non, émanant des établissements d'enseignement et de recherche français ou étrangers, des laboratoires publics ou privés. 


\section{Quaternaire}

Revue de l'Association française pour l'étude du

Quaternaire

vol. 27/4 | 2016

Volume 27 Numéro 4

\section{Database of pleistocene periglacial features in France: description of the online version}

Base de données des structures périglaciaires pléistocènes en France:

description de la version accessible en ligne

Eric Andrieux, Pascal Bertran, Pierre Antoine, Laurent Deschodt, Arnaud Lenoble, Sylvie Coutard, Aurelie Ajas, Quentin Borderie, Jean-Pierre Coutard, Francois Didierjean, Bertrand Dousteyssier, Catherine Ferrier, Philippe Gardère, Thierry Gé, Morgane Liard, Jean-Luc Locht, Henri-Georges Naton, Mathieu Rue, Luca Sitzia, Brigitte Van Vliet-Lanoe and Gérard Vernet

\section{(2) OpenEdition}

\section{Electronic version}

URL: http://journals.openedition.org/quaternaire/7717

DOI: 10.4000 /quaternaire. 7717

ISSN: 1965-0795

Publisher

Association française pour l'étude du quaternaire

\section{Printed version}

Date of publication: 1 December 2016

Number of pages: 329-339

ISSN: 1142-2904

\section{Electronic reference}

Eric Andrieux, Pascal Bertran, Pierre Antoine, Laurent Deschodt, Arnaud Lenoble, Sylvie Coutard, Aurelie Ajas, Quentin Borderie, Jean-Pierre Coutard, Francois Didierjean, Bertrand Dousteyssier, Catherine Ferrier, Philippe Gardère, Thierry Gé, Morgane Liard, Jean-Luc Locht, Henri-Georges Naton, Mathieu Rue, Luca Sitzia, Brigitte Van Vliet-Lanoe and Gérard Vernet, « Database of pleistocene periglacial features

in France: description of the online version », Quaternaire [Online], vol. 27/4 | 2016, Online since 01 December 2018, connection on 19 April 2019. URL : http://journals.openedition.org/quaternaire/7717 ; DOI : 10.4000/quaternaire.7717 


\title{
DATABASE OF PLEISTOCENE PERIGLACIAL FEATURES IN FRANCE: DESCRIPTION OF THE ONLINE VERSION
}

\author{
Eric ANDRIEUX ${ }^{1}$, Pascal BERTRAN ${ }^{2,1}$, Pierre ANTOINE ${ }^{3}$, Laurent DESCHODT ${ }^{4}$, \\ Arnaud LENOBLE ${ }^{1}$, Sylvie COUTARD ${ }^{5} \&$ collaborators*
}

\begin{abstract}
A database of Pleistocene periglacial features in France has been compiled from a review of academic literature and reports of rescue archaeology, the analysis of aerial photographs and new field surveys. Polygons, soil stripes, ice-wedge pseudomorphs, sand wedges and composite wedge pseudomorphs are included in the database together with their geographic coordinates, geological context, description and associated references. It is hoped that this database, which aim is to be integrated in broader studies will stimulate further work on past permafrost reconstruction and will favour greater understanding of the climatic events that lead to the formation of the periglacial features. The database is available online on the AFEQ-CNF INQUA website (https://afeqeng. hypotheses.org/487). A folder that contains photographs and sketches of the features is also available on request.
\end{abstract}

Keywords: permafrost, ice-wedge pseudomorphs, sand wedges, composite wedge pseudomorphs, polygons, soil stripes, France

\section{RÉSUMÉ}

BASE DE DONNÉES DES STRUCTURES PÉRIGLACIAIRES PLÉISTOCÈNES EN FRANCE : DESCRIPTION DE LA VERSION ACCESSIBLE EN LIGNE

Une base de données des structures périglaciaires pléistocènes de France a été créée à partir d'une revue de la littérature scientifique, de rapports d'archéologie préventive, de l'analyse de photographies aériennes et de nouvelles prospections de terrain Les polygones, les sols striés, les pseudomorphoses de coin de glace, les coins de sable et les pseudomorphoses de coin composite ont été répertoriés dans la base de données avec leurs coordonnées géographiques, le contexte géologique, leur description et les références bibliographiques associées. Nous espérons que cette base de données, dont le but est d'être intégrée dans des études plus larges, stimulera de prochains travaux sur la reconstitution du pergélisol pléistocène et favorisera une plus grande compréhension des événements climatiques qui ont conduit à la formation de ces structures périglaciaires. La base de données est disponible en ligne sur le site de l'AFEQ-CNF INQUA (https://afeqeng.hypotheses.org/487). Un dossier contenant les photographies et dessins des structures périglaciaires est également disponible sur demande.

Mots-clés : pergélisol, pseudomorphoses de coin de glace, coins de sable, pseudomorphoses de coin composite, polygones, sols striés, France

\section{1 - INTRODUCTION}

During the Pleistocene, periglacial landscapes have formed over large surfaces in mid-latitude Western Europe. The Mid to Late Pleistocene climate oscillations caused the land area affected by periglacial conditions to expand and contract repeatedly. Many relict periglacial features bear witness of these events and raised abundant research by geologists and geomorphologists. Aside from the engineering aspects of these discoveries, the scien- tific community focused on the climatic significance of the features, the reconstruction of past environments, and finally, the possible impact of the periglacial milieus on Palaeolithic populations.

Reconstructions of the previous extent of permafrost in Western Europe have been proposed for over 60 years (Poser, 1948; Büdel, 1951; Kaiser, 1960; Maarleveld, 1976; Lautridou \& Sommé, 1981; Velichko, 1982). Further improvements were later made using increasingly available observations on present-day permafrost

\footnotetext{
${ }^{1}$ PACEA, UMR 5199 Université de Bordeaux - CNRS, Bâtiment B18, Allée Geoffroy-Saint-Hilaire, CS 50023, FR-33615 Pessac cedex. Courriel: andrieux.e@gmail.com

2 INRAP, 140 avenue du Maréchal Leclerc, FR-33130 Bègles. Courriel : pascal.bertran@inrap.fr

${ }^{3}$ LGP, UMR 8591 Université Paris 1 - CNRS, 1 place A. Briand, FR-92195 Meudon cedex. Courriel : pierre.antoine@cnrs-bellevue.fr

${ }^{4}$ INRAP, 11 rue des champs, ZI de la Pilaterie, FR-59650 Villeneuve-d'Ascq. Courriel : laurent.deschodt@inrap.fr

${ }^{5}$ INRAP, 518 rue Saint-Fuscien, FR-80090 Amiens. Courriel : sylvie.coutard@inrap.fr
}

* Aurélie AJAS, Quentin BORDERIE, Jean-Pierre COUTARD, François DIDIERJEAN, Bertrand DOUSTEYSSIER, Catherine FERRIER, Philippe GARDERE, Thierry GE, Morgane LIARD, Jean-Luc LOCHT, Henri-Georges NATON, Mathieu RUE, Luca SITZIA, Brigitte VAN VLIET-LANOË, Gérard VERNET. 
(Péwé, 1966; Romanovskij, 1985; Mackay \& Burn, 2002; Murton, 2013), and sporadic, discontinuous and continuous Pleistocene permafrost was differentiated in the proposed maps (Vandenberghe \& Pissart, 1993; Van Vliet-Lanoë, 1989, 1996; Huijzer \& Vandenberghe 1998; Isarin et al., 1998; Van Vliet \& Hallégouët, 2001; Renssen and Vandenberghe, 2003; Vandenberghe et al., 2014). Despite the lack of agreement between these reconstructions, these studies agree that permafrost extended over large parts of France during the Pleistocene.

Most of the datasets available have been published in French language with limited circulation, and unfortunately remains largely inaccessible to the international community. During the last decade, the launch of online databases of aerial photographs (Google earth, Géoportail) has eased the recognition of periglacial features, adding a lot of new data. The huge development of rescue archaeology also increased significantly the number of identified features.

This paper serves as an introduction to an online database aiming at gathering as exhaustively as possible the features related to past permafrost in France, to give easier access to a homogenised and reliable dataset. It also reports on the main limits that should be considered when using the map or the data to make interpretations. The establishment of such a database is of the outmost importance to progress towards a better general understanding of periglacial environments.

The database was first introduced by Bertran et al. (2014), who focused on the geographic distribution of the georeferenced features and reviewed the available chronological data. Periglacial features and their characteristics were entered into a GIS to elucidate the different factors that influenced the development of periglacial features and to propose a new map of the main Pleistocene permafrost boundaries in Western Europe (Andrieux et al., 2015). We propose here an improved online version of the database illustrating and explaining identification criteria of the periglacial features gathered.

\section{2 - DATA COLLECTION, DATABASE STRUCTURE}

The selected items comprise features observed from aerial photographs and classified in (i) polygonal networks and (ii) soil stripes, and features observed in cross-section and classified in (iii) sand wedges, (iv) icewedge pseudomorphs, and (v) composite wedge pseudomorphs. Involutions, patterned grounds other than soil stripes, pingo and lithalsa scars, which are also considered potentially testifying to past permafrost, have not been integrated into the database, since re-evaluation of the features mentioned in the literature is still under progress. They will be added to the database at the end of this process. Similarly, mountain permafrost features were not included in the database.
Multi-user tests were performed on the photographs to be sure that only indisputable features were added to the database. When different features were present on the same site, it appears in the file of the most represented type. Search for periglacial features in aerial photographs have been made primarily in areas where some had been previously reported in the literature. Search was then extended to neighbouring regions. In this process, it became rapidly obvious that many features were preferentially associated with specific substrates, for example old (Lower Pleistocene and Tertiary) alluvial sand and gravel deposits for polygons, chalk with a thin loess cover for soil stripes... Blind tests in other regions were also made but were most of the time unsuccessful.

We also conducted a thorough search of the published literature on periglacial features in France, including articles in journals, $\mathrm{PhD}$ theses, other dissertations (often unpublished) and geology reports of rescue archaeology. These data were rigorously selected and all entries not accompanied by drawings, photographs or good descriptions were rejected from the database. We were forced to exclude a significant amount of features because the sources did not document them enough (lack of description or figure) or did not give satisfying geographic information (e.g. coordinates, grid references).

The investigated literature covers the last 60 years, and during such a time span the overall understanding and classification of the periglacial processes changed significantly. In the 50's, the research community lead by A. Cailleux and J. Tricart (Bastin \& Cailleux, 1941; Cailleux, 1948, 1956; Tricart, 1963; Tricart \& Cailleux, 1967) described abundant features assumed to be of periglacial origin in France, proving that Pleistocene frost-induced processes played a major role in shaping the landscape. Many were also mentioned in the explanatory notes accompanying the sheets of the geological map of France. "Fente de gel" (i.e. frost crack) and "fente en coin" (i.e. wedge) were used as general terms for wedges and cracks regardless their filling and width. As a consequence, with few exceptions (e.g. Michel, 1975; Yvard, 1968; Nury \& Roux, 1969; Arnal, 1971), the "frost crack" data remains hardly usable within the frame of the current database.

A total of 615 sites have been identified. In aerial photographs, a site corresponds to a single land parcel or a few adjacent parcels.

The database consists of $5 \mathrm{CSV}$ (Comma-Separated Values) files each dedicated to a single type of feature. The CSV format was chosen because of its simple use and the possibility of easy transformation into an attribute table in a GIS. Each CSV file is accompanied with a folder that contains photographs and sketches of the features when available. The ID number allows linking the listed features and corresponding pictures, drawings, or aerial photographs.

The basic fields documented are as follows: - ID, the identification number of the feature; 
- Longitude and Latitude in decimal degrees in the EPSG:4326 (WGS84) coordinate reference system;

- Altitude, derived from the DEM Aster GDEM 30 m;

- Site, the name of the place;

- City, the municipality;

- Region, the administrative region;

- Geol_code, the code of the geological substrate as shown in the 1:50,000 geological map of France (infoterre.brgm.fr);

- Substrat, the (simplified) lithology of the geological substrate as indicated in the explanatory note of the 1:50,000 geological map. "/" stands for "above";

- Reference, the bibliographic references when available;

- Photo_credit, the author of the photograph(s) or drawing(s) when available.

Additional fields are also provided for each type of features. They include:

- Size, the average size of the polygons calculated with the software ImageJ (see Andrieux et al., 2015, for detailed explanation of the measurement protocol);

- Spacing, the average spacing of the soil stripes calculated with the software ImageJ;

- Slope, the average slope gradient (in degrees) of the soil stripes derived from the DEM Aster GDEM 30 m;

- Expo, the orientation of the soil stripes (in degrees) measured on Google earth with the "ruler" tool;

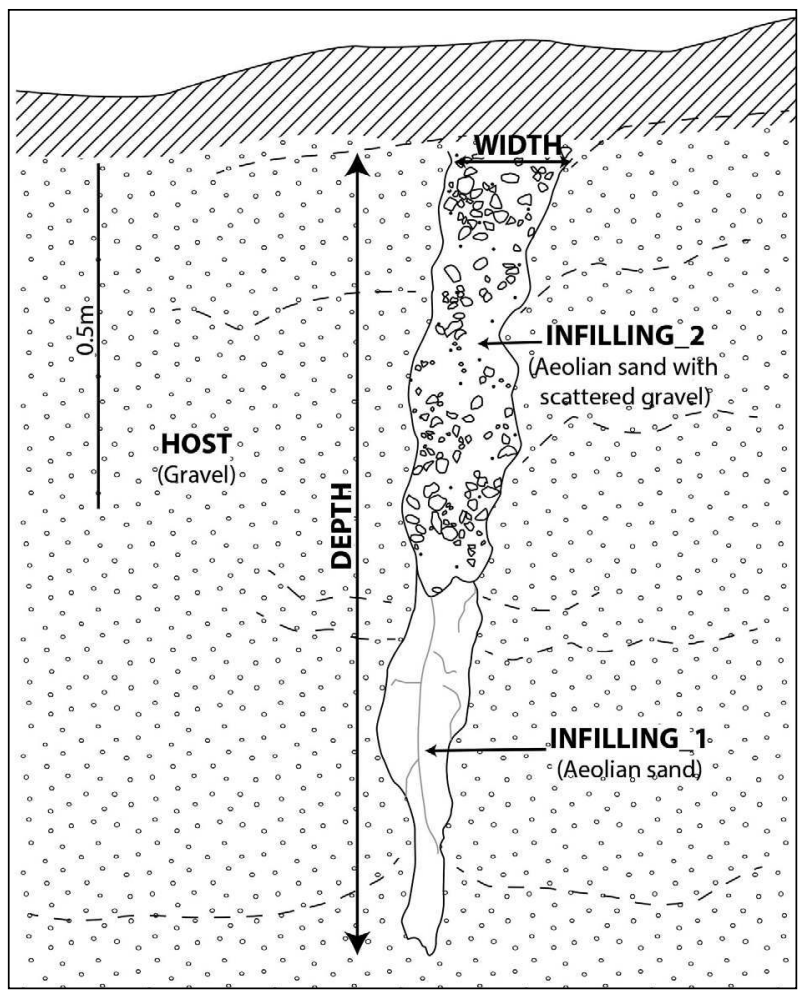

Fig. 1: Terms used for wedge description.

This composite wedge pseudomorph is located in Mérignac (Chronopost, $44^{\circ} 49^{\prime} 37.2^{\prime \prime} \mathrm{N}, 0^{\circ} 41^{\prime} 23.999^{\prime \prime} \mathrm{W}$ )

Fig. 1 : Termes utilisés pour la description des coins. La pseudomorphose de coin composite représentée provient du site de Chronopost à Mérignac (4449'37.2'”, $0^{\circ} 41$ '23.999”' W).
- Host, the lithology of the host material of the wedges determined from the description of the cross-section (fig. 1);

- Filling_1, the lithology of the main filling of the wedge;

- Filling_2, in case of different types of filling;

- Depth and Width, the dimensions of the wedges (Depth $=$ null if the apex of the wedge is not visible).

Most of the features remain non dated at the moment. The chronological data have not been included in the database, they are accessible through the cited references.

\section{3 - FEATURES DESCRIPTION}

\section{1 - POLYGONS}

When frozen ground cools down rapidly, it contracts and cracks if the tensile stress is not relieved by creep (Lachenbruch, 1962, 1966). Thermal contraction cracking occurs widely in areas subjected to deep freezing where snow and vegetation covers are thin (Mackay, 1993; Mackay \& Burn, 2002; Fortier \& Allard, 2005), with or without permafrost (Washburn et al., 1963; Friedman et al., 1971; Romanovskij, 1985). Thermal contractions cracking forms large polygonal networks of fissures, evolving into $\mathrm{V}$ shaped wedges as a consequence of repeated filling by ice or sediment. The 284 fossil polygon sites listed in the database and found in aerial photographs are between 8 and $20 \mathrm{~m}$ in diameter (mean $=15 \mathrm{~m}$, Andrieux et al., 2015). Most of the polygons observed in the lower Loire and Rhône valleys have sharp edges and thin walls, which appear darker than the surrounding land in aerial photographs (fig. 2A, B). Cross-sections discovered in the vicinity of a few sites suggest that the walls correspond to sand wedges or composite wedges. In the Paris basin and the north of France, some polygons have more rounded outlines and walls of irregular width (fig. 2C, D). They are thought to correspond to former ice-wedge polygons that have undergone thermokarstic degradation. Polygons in vineyards such as those in the Médoc region, southwest France, are often hardly visible in aerial photographs. Although not very conclusive by themselves, some photographs have been kept in the database because of the discovery of sand wedges in nearby cross-sections (Lenoble et al., 2012; Bertran et al., 2014). Aerial photographs also revealed fields of irregular and rounded "polygonal" features showing more heterogeneous sizes than typical ice or sand wedge polygons (fig. 3). Although a periglacial origin seems probable, their classification as thermal contraction features rather than very large patterned grounds remains doubtful (see aerial photographs and cross-sections in Agache, 1963, 1970) and needs further confirmation by field survey. As a consequence, this kind of features was not added to the database. 

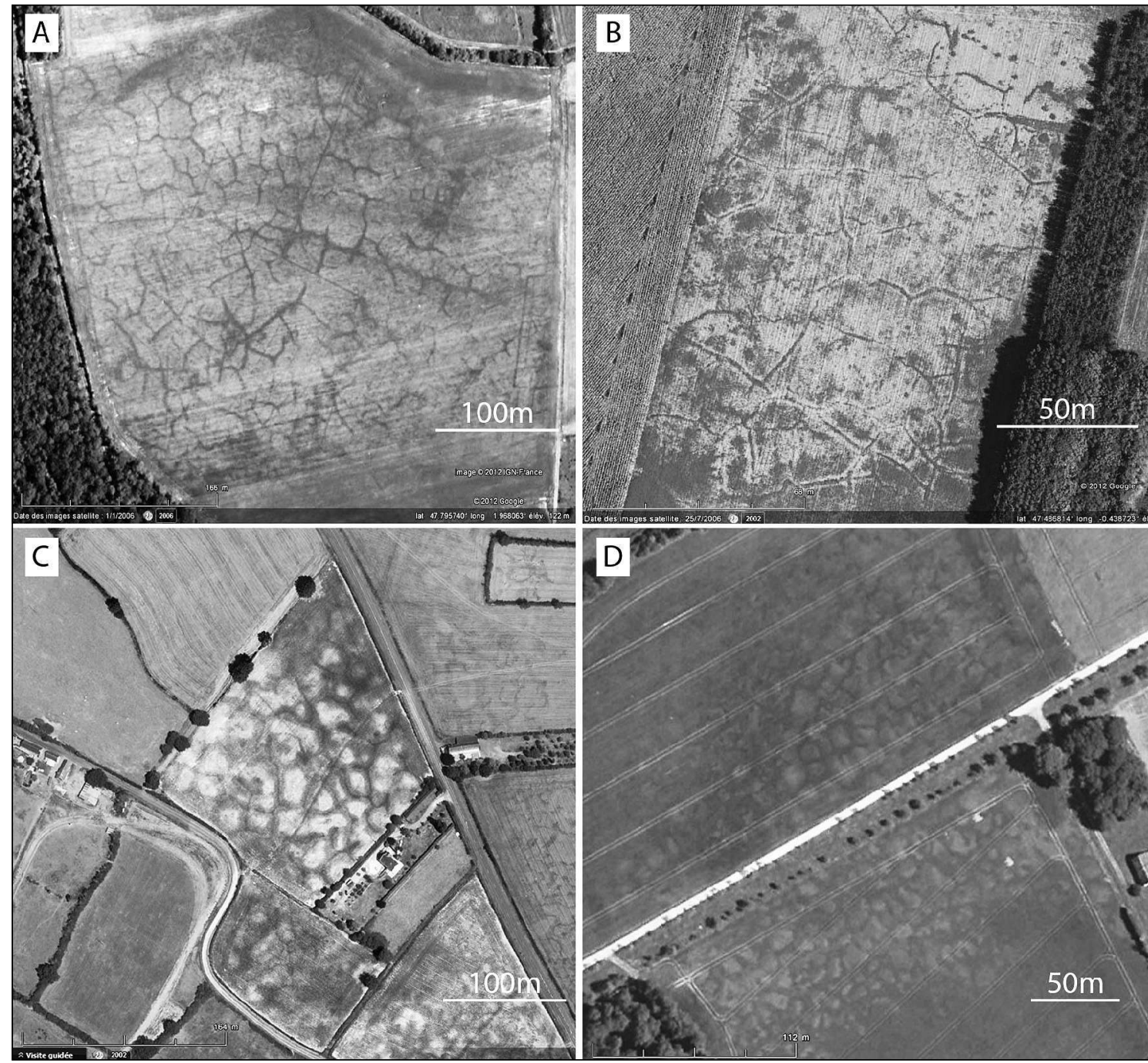

Fig. 2: Polygons.

Polygons with sharp edges and thin walls at (A) Marcilly-en-Villette $\left(47^{\circ} 47^{\prime} 49.2^{\prime \prime} \mathrm{N}, 1^{\circ} 58^{\prime} 15.6^{\prime \prime} \mathrm{E}\right)$ and (B) Le Plessis-Grammoire (47029'13.2” $\mathrm{N}$, $\left.0^{\circ} 26^{\prime} 16.799^{\prime \prime} \mathrm{W}\right)$; polygons with rounded outlines due to thermokarstic degradation of the wedges at (C) Cantenay-Epinard $\left(47^{\circ} 32^{\prime} 31.2^{\prime \prime} \mathrm{N}\right.$,

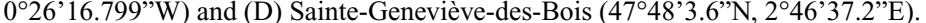

Fig. 2 : Réseaux polygonaux. Polygones avec des cloisons nettes et étroites à (A) Marcilly-en-Villette $\left(47^{\circ} 47^{\prime} 49.2^{\prime \prime} N, 1^{\circ} 58^{\prime} 15.6^{\prime \prime}\right.$ E) et (B) Le PlessisGrammoire (47029'13.2" $\left.\mathrm{N}, 0^{\circ} 26^{\prime} 16.799^{\prime \prime} \mathrm{W}\right)$; polygones avec des contours arrondis liés à la dégradation thermokarstique de coins de glace à (C)

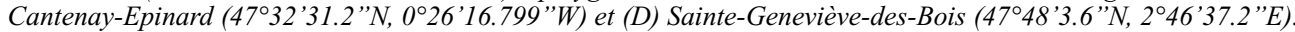
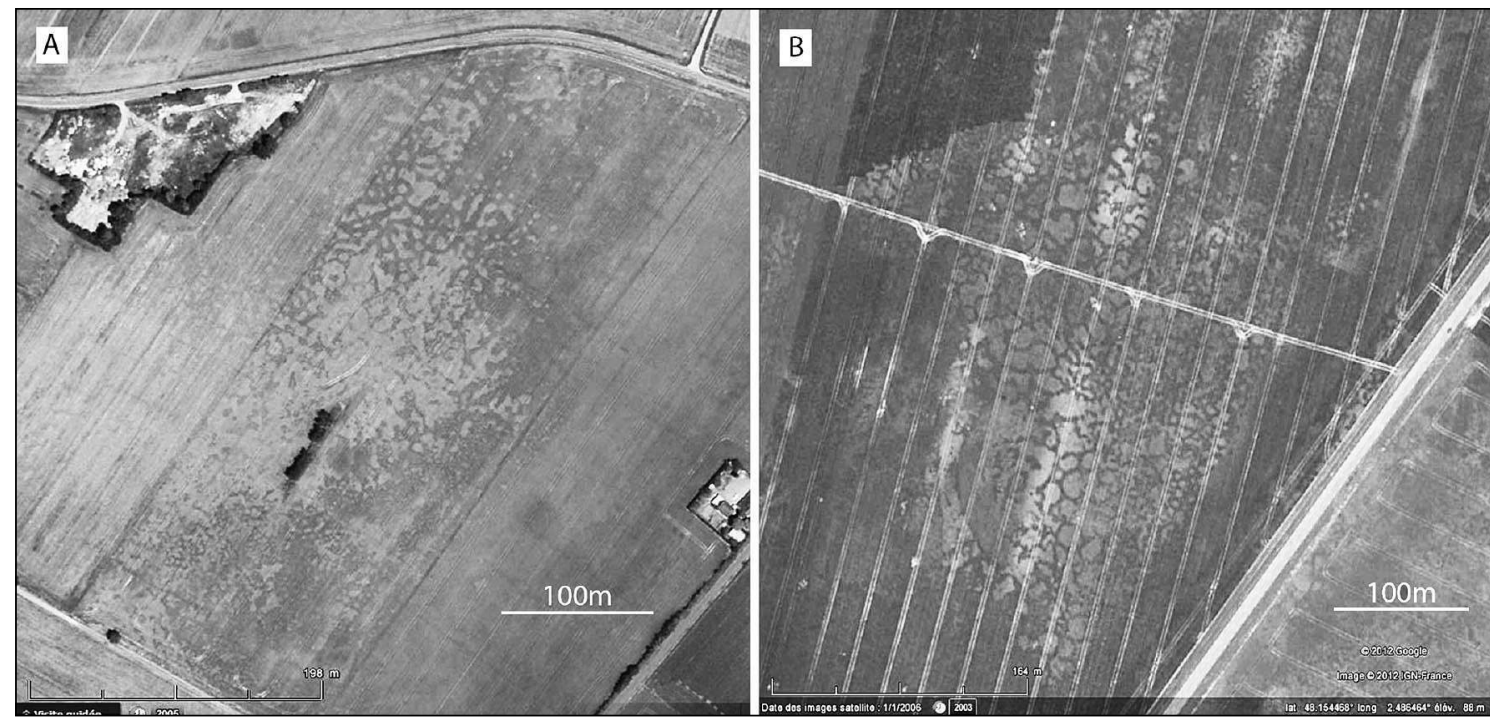

Fig. 3: Irregular polygonal patterns.

A/ Beaumont-du-Gâtinais $\left(48^{\circ} 9^{\prime} 10.8^{\prime} \mathrm{N}, 2^{\circ} 29^{\prime} 20.399^{\prime} \mathrm{E}\right)$. B/ Poillé-sur-Vègre $\left(47^{\circ} 55^{\prime} 22.8^{\prime} \mathrm{N}, 0^{\circ} 16^{\prime} 22.8^{\prime \prime} \mathrm{W}\right)$.

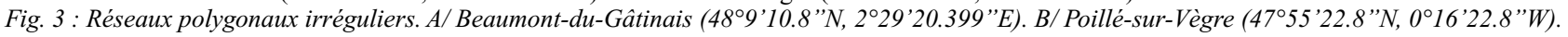


Small-scale polygons up to $1 \mathrm{~m}$ in diameter have been widely reported during field surveys but were not included in the database. They are assumed to reflect mostly (cryo-) desiccation fissures (Washburn, 1979; Van Vliet-Lanoë \& Langohr, 1981).

\section{2 - ICE-WEDGE PSEUDOMORPHS}

Ice-wedge pseudomorphs, i.e. the features left by the melt of an ice-wedge, have been widely reported in France. Severe selection was made among the reported features, 90 ice wedge pseudomorphs are listed in the database. According to Black (1976), Washburn (1979), Vandenberghe (1983), Gozdzik (1994) and Murton (2013), the main criteria for their identification and consideration in the database are: (1) a V shape showing collapse structures due to the replacement of ice; these consist in block faulting (common in the coversands of northern Europe, Murton, 2013; no example has been found in France so far, fig. 4C), downturned strata in the host material or folding of the strata toward the wedge, vertically aligned clasts along the walls of the pseudomorph (mainly in gravel); (2) a minimum size of $0.2 \mathrm{~m}$ in width and $1.5 \mathrm{~m}$ in height, (3) deformation of the host material (upturned strata, vertical gravel pebbles) due to wedge growth, (4) evidence for a polygonal pattern from cross-sections or aerial photographs. The filling may be massive or show steeply dipping or U-shaped layers. Blocks of sediment may be present within the filling (fig. 4B). In loess deposits ice-wedge pseudomorphs are usually associated with a cryoturbated bleached layer with small ferruginous spots, interpreted as a former gley soil over permafrost (Gullentops, 1954; Haesaerts \& Van Vliet-Lanoë, 1973; Antoine et al., 2009, fig. 4A). Thermokarstic degradation of permafrost may lead to the erosion and deformation of the wedge, the formation of tunnels, ponds and gullies so that the relict ice-wedges are no longer identifiable or visible. The distribution of ice wedge pseudomorphs is therefore probably significantly underestimated in our dataset.

Not included in the database are many wedge structures described in France in the literature. They are narrow and lack any clear indication of host material collapsed in the wedge after the melt of an ice body (fig. 5). These features may represent either incipient ice wedges (ice veins) or soil wedges in seasonally frozen ground (Friedman et al., 1971; Romanovskij, 1973; Murton, 2013).

\section{3 - SAND-WEDGES}

The primary filling of thermal contraction cracks by wind-blown sand forms sand wedges (Péwé, 1959; Black, 1976; Washburn, 1979; Kolstrup, 1986; Gozdzik, 1986; Murton, 1996; Bockheim et al., 2009). Sand wedges do not show evidence of host material slumped in the wedge. They are usually V-shaped but may be irregular with multiple elementary sand veins extending out of the toe of the wedge into the host material (this typically occurs in sands, Romanov- skij, 1976; Murton et al., 2000) (fig. 6A), or have a "bulbous" shape (fig. 6B). The origin of the bulbous shape, illustrated by Murton et al. (2000) in Poland, remains uncertain. In our dataset, they were observed only in fine-grained substrates and may reflect deformation during the thawing of an ice-rich host sediment or deformation of the seasonally frozen layer due to frost heave (Jetchick \& Allard, 1990; Van Vliet-Lanoë, 2005). Deformation of the host material induced by wedge growth is usually poorly developed and upward bending of strata occurs only occasionally. Field exposures generally show multiple sand wedges a few metres apart, which testifies to a polygonal pattern. The sand wedges identified in France have generally a massive filling (fig. 6C) but show sometimes vertical laminations (fig. 6D). According to Péwé (1959) and Murton \& Bateman (2007), the lack of vertical lamination does not necessarily imply a secondary perturbation caused by the thaw of ice veins. Small eolised gravels may occasionally be present in the upper part of the filling and have probably felt into the fissures during the opening of the wedges (Péwé, 1959) (fig. 6E).

In the database, 82 sand wedges are listed. Only the wedges with a minimum width of $0.2 \mathrm{~m}$ and $0.5 \mathrm{~m}$ in height were added to the database to be sure to not consider possible desiccation or extension cracks filled by sand.

\section{4 - COMPOSITE-WEDGE PSEUDOMORPHS}

Composite wedges are thermal contraction cracks filled both by wind-blown sand and ice (Kolstrup, 1986; Murton, 1996; Murton et al., 2000, 2007; Antoine et al., 2005). The composite wedges share therefore common features with ice-wedge pseudomorphs and (primary) sand wedges. The most diagnostic feature is the evidence of a secondary filling occupying a significant part of the wedge. This filling appears typically either as crossstratified to U-shaped beds of sand or gravel material (fig. 7A, B) or as a mixture of well-sorted (aeolian) sand with scattered gravel in the whole mass. Only wedges with a significant part of the filling showing U-shaped stratification were considered as composite wedge pseudomorphs since simple sand wedges may exhibit such a stratification in the upper decimetres as shown by Péwé (1959). In many cases, however, the wedges show different types of filling cross-cutting each other, suggesting a succession of dominantly icy or sandy phases (fig. 7C). One example (fig. 7D) corresponds to a gully overlying a truncated sand wedge. The gully is thought to be of thermokarstic origin and, therefore, suggests that the wedge filling contained a significant amount of ice. Overall, 10 composite-wedge pseudomorphs are listed in the database. However, this number may be underestimated because of difficulties in identifying secondary sandy fillings. Potential composite wedge pseudomorphs may, therefore, be classified here as sand-wedges. 


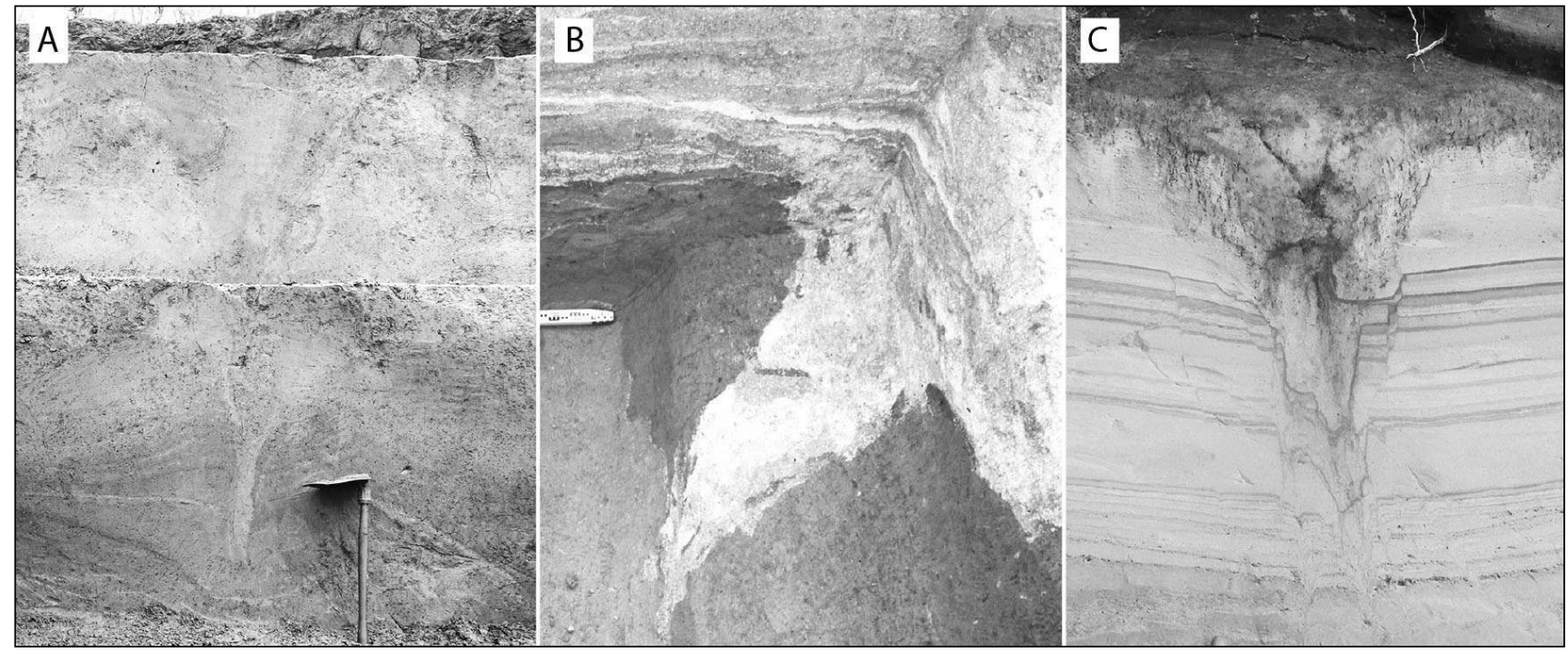

Fig. 4: Ice-wedge pseudomorphs.

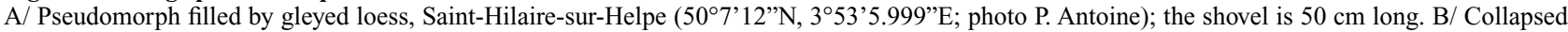
blocks of loess in a pseudomorph, Corbie $\left(49^{\circ} 55^{\prime} 48^{\prime \prime} \mathrm{N}, 2^{\circ} 28^{\prime} 47.999^{\prime \prime} \mathrm{E}\right.$; photo P. Antoine). C/ Pseudomorph with faulted blocks along the walls in coversands, Lutterzand, the Netherlands.

Fig. 4: Pesudomorphoses de coin de glace. A/ Pseudomorphose remplie par des loess gleyifiés à Saint-Hilaire-sur-Helpe (50 7'12 "N, 3053'5.999"'E;

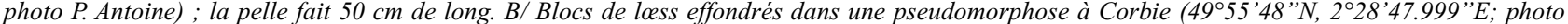
P. Antoine). C/ Pseudomorphose de coin de glace avec des blocs glissés le long des parois dans des sables de couverture à Lutterzand, Pays-Bas.
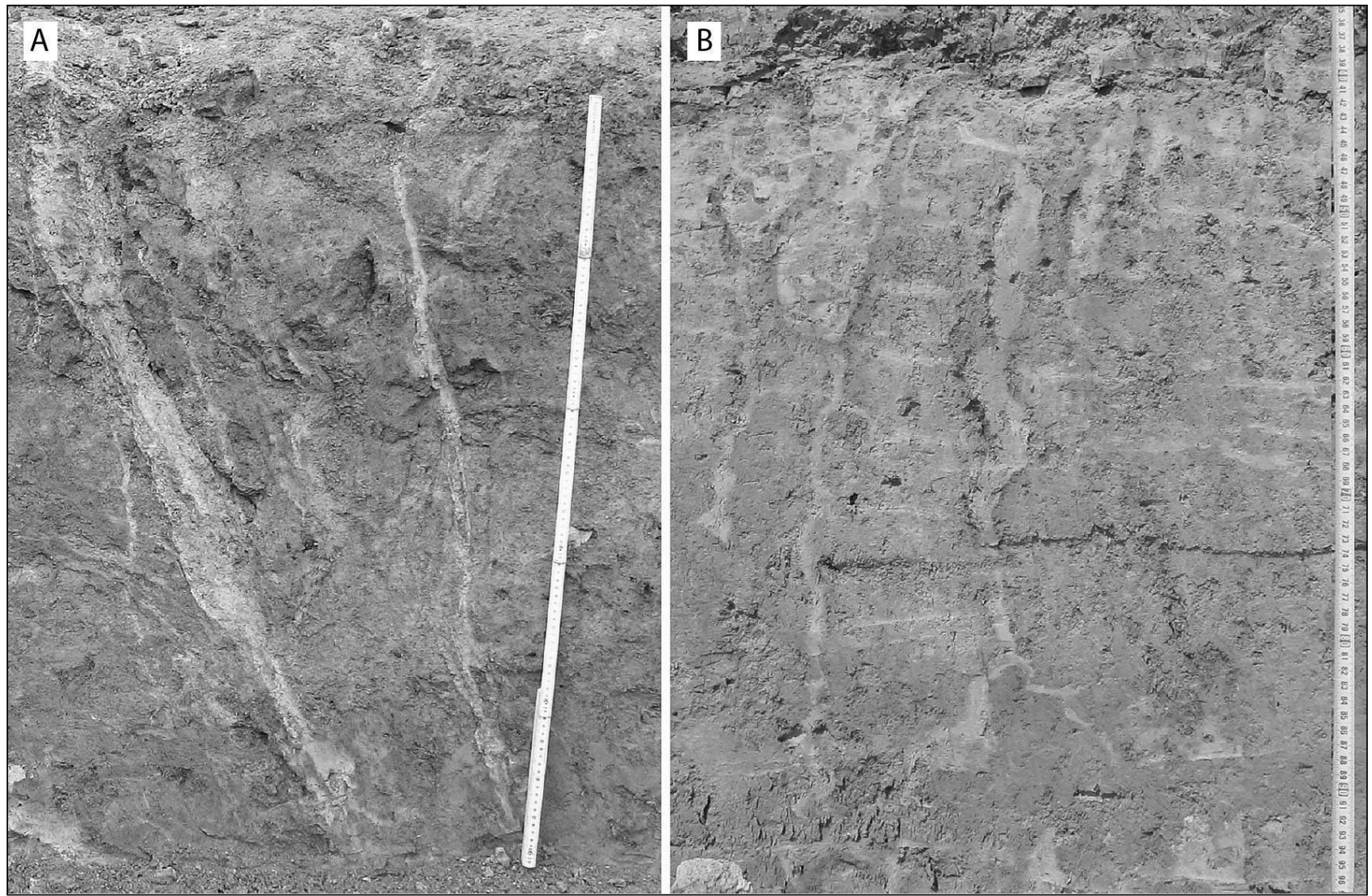

Fig. 5: Fissures interpreted as (cryo-)desiccation or thermal contraction cracks in a seasonally frozen ground.

$\mathrm{A} /$ Combebrune 2 and $\mathrm{B} /$ Romentères. The host material is colluviated aeolian silt. Both features located in the southwest of France form small-scale polygons in plan view ( 0.5 to $1 \mathrm{~m}$ in diameter). Although the digitations suggest repeated cracking, no evidence for ice melt and subsequent filling is visible. The fissures were secondarily affected by redox processes and bleaching due to waterlogging. In photo B, bleached horizontal fissures suggest that ice lenses formed in connection with the vertical fissures. The scale is $1 \mathrm{~m}$ long.

Fig. 5 : Fentes interprétées comme des fissures de (cryo-)dessiccation ou de contraction thermique dans un sol gelé saisonnièrement. A/ Combebrune 2 et B/Romentères. Le matériel encaissant est composé de limons éoliens colluvionnés. Ces structures, situées dans le sud-ouest de la France, forment en plan des petits polygones de 0,5 à $1 \mathrm{~m}$ de diamètre. Bien que les digitations suggèrent une fissuration répétée, aucun indice de la fonte d'un corps de glace n'est visible. Les fissures ont été affectées secondairement par des processus d'oxydoréduction et un blanchiment lié à un engorgement temporaire. Dans la photo B, les fissures horizontales blanchies suggèrent que des lentilles de glace se sont formées en connexion avec les fissures verticales. L'échelle fait $1 \mathrm{~m}$ de long. 

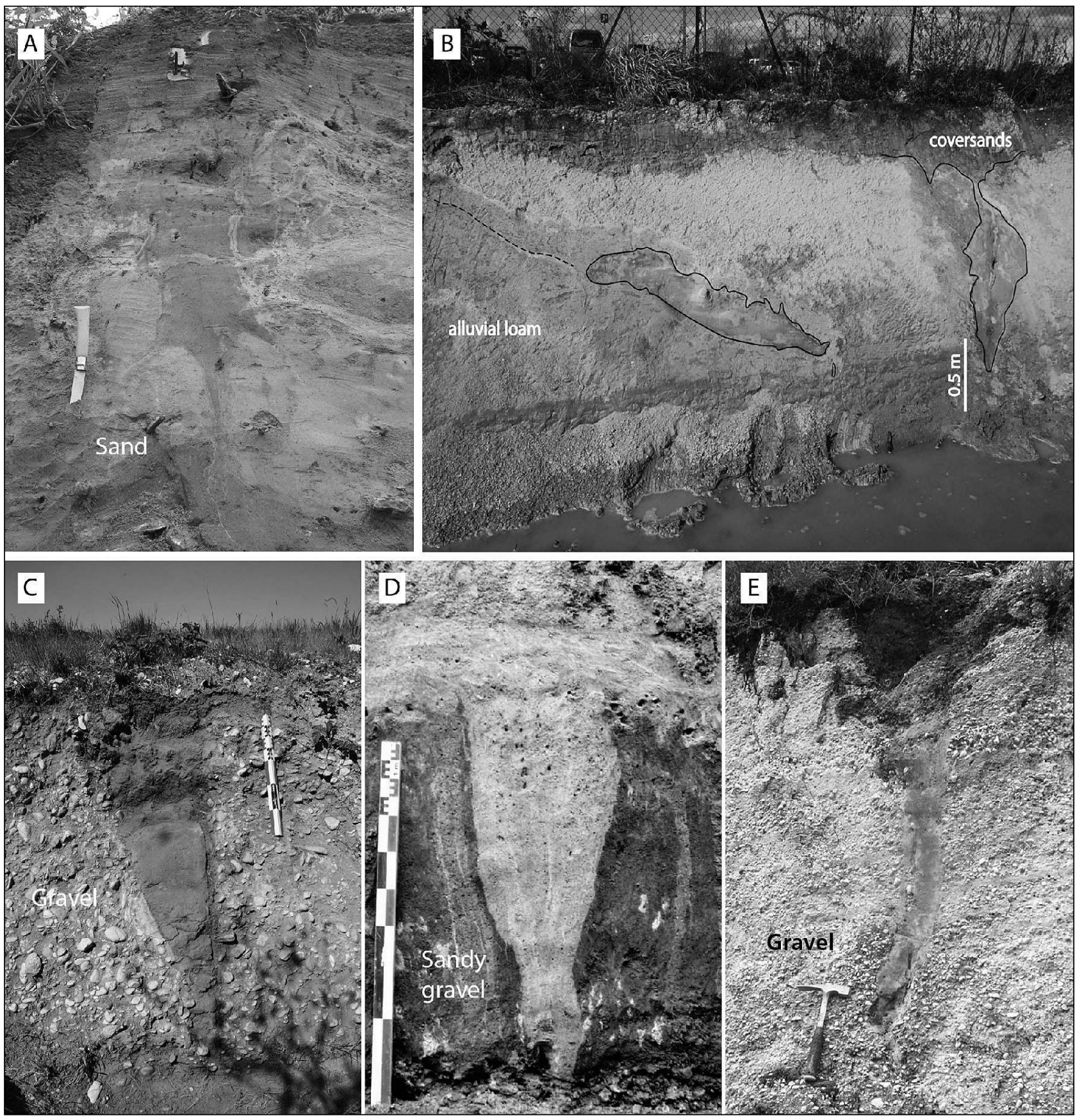

Fig. 6: Sand wedges.

$\mathrm{A} /$ Sand wedge with multiple elementary sand veins extending out of the toe in Saint-Amand-les-Eaux (Mont-des-Bruyères, 50 $26^{\prime} 16.8^{\prime \prime} \mathrm{N}, 3^{\circ} 26^{\prime} 34.8^{\prime \prime} \mathrm{E}$ ); the knife is ca. $20 \mathrm{~cm}$ long. B/ Sand wedges with a bulbous shape in Mérignac (Chronopost 1, 4449'37.2”N, 041'23.999”'W). C/ Sand wedge with massive sand filling in Cussac-Fort-Médoc (Déchetterie, $45^{\circ} 7^{\prime} 19.2^{\prime} \mathrm{N}, 0^{\circ} 45^{\prime} 3.6^{\prime} \mathrm{W}$ ); the scale is $50 \mathrm{~cm}$ long. D/ Sand wedge with vertical lamination in Joze (45'52'12”N, $3^{\circ} 17^{\prime} 24^{\prime \prime} \mathrm{E}$; photo G. Vernet); the scale is $1 \mathrm{~m}$ long. E/ Small eolised gravels in the top part of a sand wedge in Léognan (Lac Bleu $44^{\circ} 43^{\prime} 15.6$ 'N, 037'29.999' W); the hammer is ca. $35 \mathrm{~cm}$ long.

Fig. 6 : Coins sableux. A/ Coin sableux avec de multiples veines élémentaires dans le prolongement de l'apex du coin à Saint-Amand-les-Eaux (Montdes-Bruyères, 50²6’16.8”N, 326’34.8”E) ; le couteau fait $20 \mathrm{~cm}$ de long. B/ Coins sableux avec une forme en bulbe à Mérignac (Chronopost

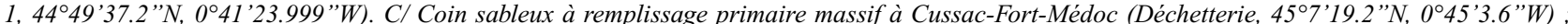
l'échelle fait $50 \mathrm{~cm}$ de long. D/ Coin sableux avec des laminations verticales à Joze $\left(45^{\circ} 52^{\prime} 12^{\prime \prime} N, 3^{\circ} 17^{\prime} 24^{\prime \prime} E\right.$; photo G. Vernet) ; l'échelle fait $1 \mathrm{~m}$ de long. E/ Petits graviers éolisés dans la partie supérieure du remplissage d'un coin sableux à Léognan (Lac Bleu 4443'15.6”'N, 0³7'29.999’'W); le marteau fait $35 \mathrm{~cm}$ de long.

\section{5 - STRIPES}

Stripes appearing in aerial photographs of ploughed fields are regularly spaced stripes of different colours, some of which are branched. They reflect alternating bands of light coloured (usually chalky) debris and darker loess or clay loam material or uneven plant growth due to contrasts in water content (fig. 8A, B). A small number of aerial photographs show spotted patterned ground on flat surfaces stretching into stripes on slopes (fig. 8D, C). A total of 149 sites of relict soil stripes have been identified in France, mostly in the Paris basin. The spacing between the stripes range from 2 to $13 \mathrm{~m}$, but the distribution can be adjusted to two Gaussian functions peaking at 4.6 and 

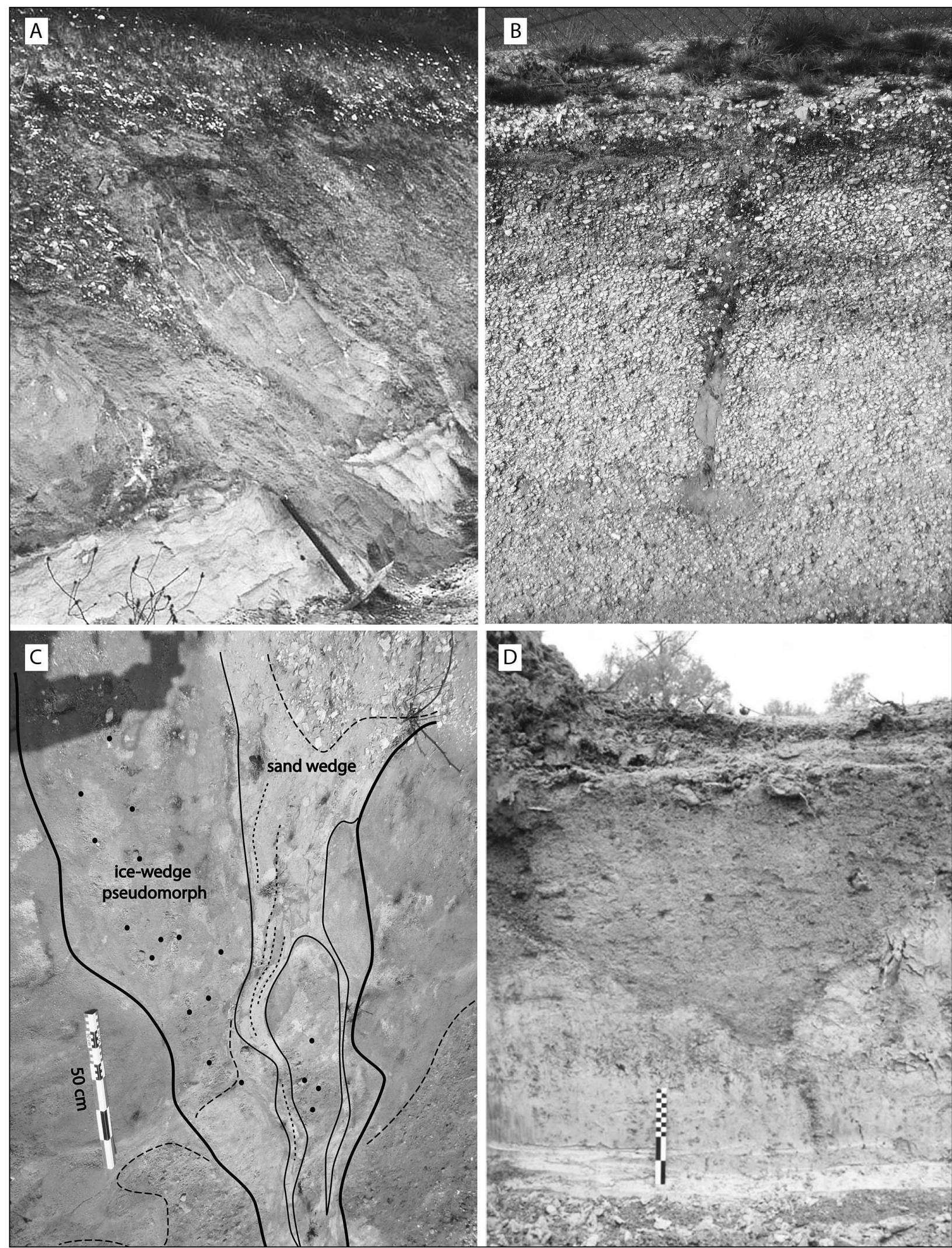

Fig. 7: Composite wedge pseudomorphs.

A/ Pseudomorph with a two-phase filling (sand, gravel) in Lessay $\left(49^{\circ} 12^{\prime} 42.84^{\prime \prime} \mathrm{N}, 1^{\circ} 31^{\prime} 52.859^{\prime \prime} \mathrm{W}\right.$; photo J. P. Coutard); the pickaxe is $1 \mathrm{~m}$ long.

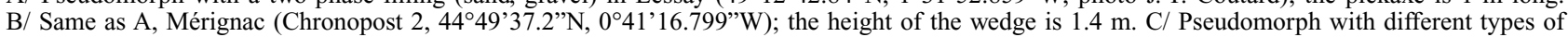
filling cross-cutting each other suggesting a first dominantly icy phase then a sandy one in Durtal $\left(47^{\circ} 39^{\prime} 36^{\prime \prime} \mathrm{N}, 0^{\circ} 13^{\prime} 51.6^{\prime \prime} \mathrm{W}\right)$. D/ Thermokarstic gully

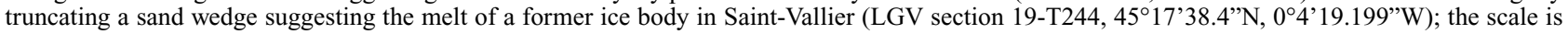
$40 \mathrm{~cm}$ long.

Fig. 7 : Pseudomorphoses de coin composite. A/Pseudomorphose avec un remplissage biphasé (sable, gravier) à Lessay (9 $\left.9^{\circ} 12^{\prime} 42.84^{\prime \prime} \mathrm{N}, 1^{\circ} 31^{\prime} 52.859^{\prime \prime} \mathrm{W}\right)$

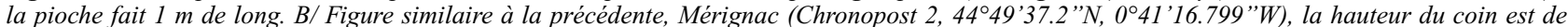
$1,4 \mathrm{~m}$. C/ Pseudomorphose avec deux générations successives de remplissage suggérant une première phase de type coin de glace, recoupée par une phase plus récente de type coin sableux à Durtal $\left(47^{\circ} 39^{\prime} 36^{\prime}\right.$ "N, $0^{\circ} 13^{\prime} 51.6^{\prime}$ "W). D/ Ravin probablement d'origine thermokarstique tronquant un coin à remplissage sableux suggérant la fonte d'un ancien corps de glace à Saint-Vallier (LGV section 19-T244, 4517'38.4"N, 04'19.199"'W) ; l'échelle fait $40 \mathrm{~cm}$ de long. 

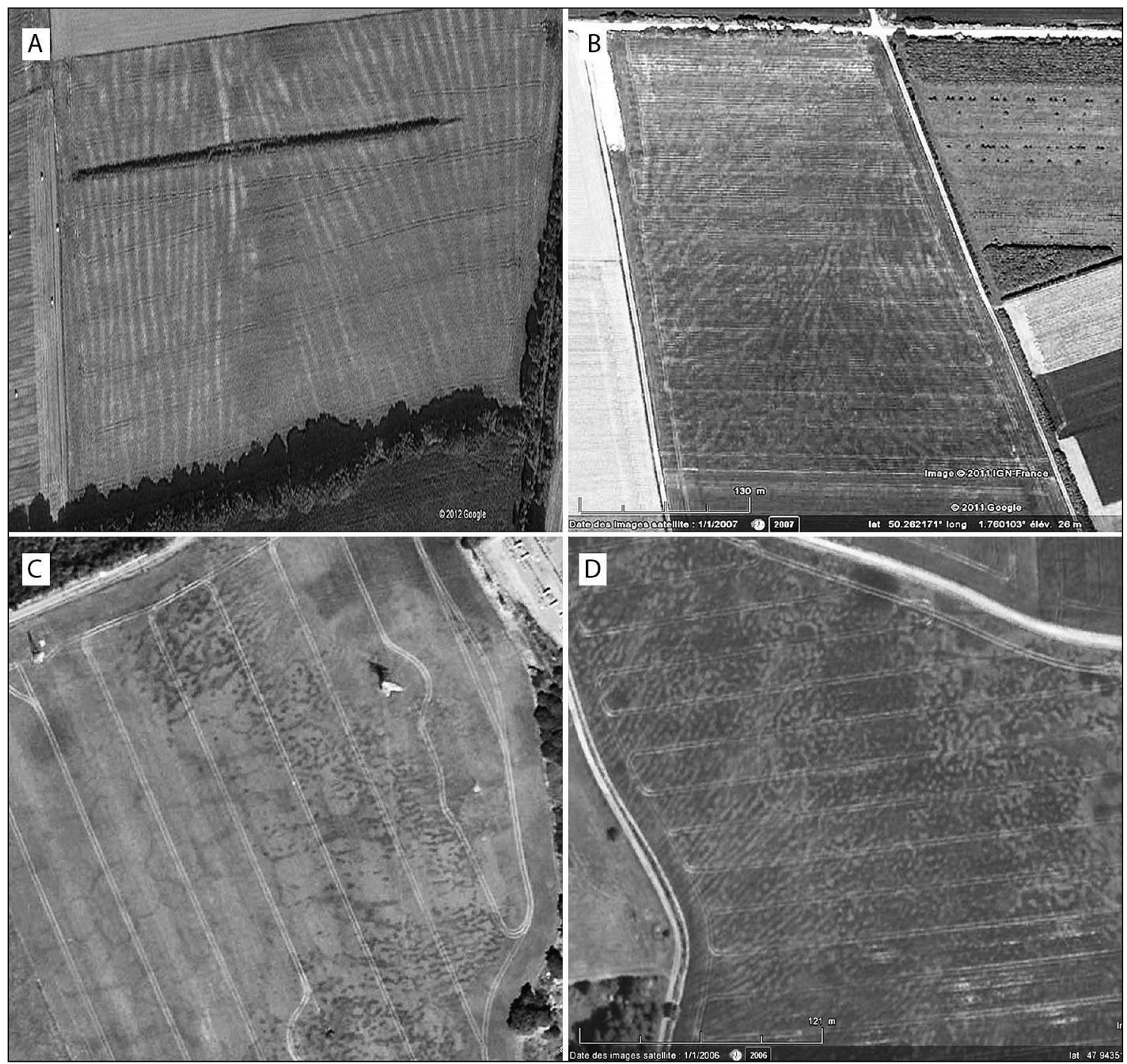

Fig. 8: Soil stripes.

A/ Airon-Saint-Vaast $\left(50^{\circ} 26^{\prime} 24^{\prime} \mathrm{N}, 1^{\circ} 40^{\prime} 30^{\prime \prime} \mathrm{E}\right)$. B/ Le Crotoy $\left(50^{\circ} 12^{\prime} 10.8^{\prime \prime} \mathrm{N}, 1^{\circ} 49^{\prime} 12^{\prime \prime} \mathrm{E}\right)$. C/ Small patterned ground (rounded cells) stretching into stripes on slopes in Fontenay (48 $\left.6^{\prime} 36^{\prime \prime} \mathrm{N}, 2^{\circ} 46^{\prime} 51.6^{\prime \prime} \mathrm{E}\right)$ and $\mathrm{D} /$ Triguères $\left(47^{\circ} 566^{\prime} 34.8^{\prime \prime} \mathrm{N}, 2^{\circ} 58^{\prime} 12^{\prime \prime} \mathrm{E}\right)$.

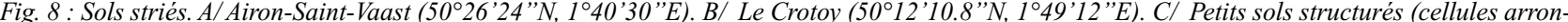
dies) s'étirant en stries sur versant à Fontenay $\left(48^{\circ} 6^{\prime} 36^{\prime \prime} \mathrm{N}, 2^{\circ} 46^{\prime} 51.6^{\prime \prime} \mathrm{E}\right)$ et D/ Triguères $\left(47^{\circ} 56^{\prime} 34.8^{\prime \prime} \mathrm{N}, 2^{\circ} 58^{\prime} 12^{\prime \prime} \mathrm{E}\right)$.

$7.9 \mathrm{~m}$, which seem to be mostly related to the nature of the substrate (Andrieux et al., 2015). The largest stripes are found north of $49^{\circ} \mathrm{N}$. Similar features were described previously in the UK amongst others by Williams (1964, 1968) and Ballantyne \& Harris (1994). In modern periglacial environments, soil stripes form in the ground layer subjected to freezing and thawing cycles. They are found in seasonally frozen grounds, but are most developed over permafrost (Washburn, 1979; Ballantyne \& Harris, 1994).

\section{4 - CONCLUSIONS}

The aim of this database is to be integrated in broader studies and to be progressively completed with the implementation of new field evidence of periglacial features. The data presented here should not be viewed as fully exhaustive; because of limited time and funds all the potential areas where periglacial features could be found in cross-sections have not been prospected yet. This is particularly the case for large areas of northeast France. Updating the database will make it possible to reconstruct more reliably past permafrost and to shed new light on some questions, such as the controlling factors of the gaps in deep aquifer recharge during the Late Pleistocene (Jiraková et al., 2011), the gaps in speleothem growth (Genty et al., 2010), and fluctuations of the peopling of vast regions of northern Europe during the Palaeolithic (Miller, 2012; Tallavaara et al., 2015). Conflicts and discrepancies may remain as shown by Andrieux et al. (2015) and few data exist with regard of the age of the features. To solve these issues further research on the origin and palaeoclimatic significance of some features and more thorough dating is needed. The online database can be downloaded at https://afeqeng.hypotheses.org/487 and used provided that this paper is cited in the references. The file of photographs and drawings is available on request from the first two authors (E. A. and P. B.). 


\section{ACKNOWLEDGMENTS}

This work benefitted from funds provided by the INRAP, the Lascarbx (program of the Agence Nationale de la Recherche ANR-10-LABX-52), the University of Bordeaux and the UMR-5199 PACEA. C. Kasse and J. Vandenberghe presented to the authors the section illustrated in fig. 4A. We also acknowledge M. Bateman and J. Vandenberghe whose remarks have improved the manuscript.

\section{REFERENCES}

AGACHE R., 1963 - Informations archéologiques. Compte-Rendu de directeur de la circonscription préhistorique de Lille. Gallia Préhistoire VI, 165-180.

AGACHE R., 1970 - Détection aérienne de vestiges protohistoriques, gallo-romains et médiévaux dans le bassin de la Somme et ses abords. Bulletin de la Société de Préhistoire du Nord, n spécial 7, 230 p.

ANDRIEUX E., BERTRAN P. \& SAITO K., 2015 - Spatial analysis of the French Pleistocene permafrost by a GIS database. Permafrost and Periglacial Processes, 27 (1), 17-30.

ANTOINE P., MARCHIOL A., BROCANTEL M. \& GROS Y., 2005 - Découverte de structures périglaciaires (sand-wedges et composite-wedges) sur le site de stockage de déchets radioactifs de l'Aube (France). Comptes Rendus Géosciences, 337 (16), 1462-1473.

ANTOINE P., ROUSSEAU D. D., MOINE O., KUNESCH S., HATTÉ C., LANG A., TISSOUX H. \& ZÖLLER L., 2009 - Rapid and cyclic aeolian deposition during the Last Glacial in European loess: a high-resolution record from Nussloch, Germany. Quaternary Science Reviews, 28 (25-26), 2955-2973.

ARNAL H., 1971 - Les sols polygonaux étirés et sols striés d'âge würmien de Laudun (Gard). Bulletin de l'Association Française pour l'Etude du Quaternaire, 8 (3), 151-160.

BALLANTYNE C.K. \& HARRIS C., 1994 - The periglaciation of Great Britain. Cambridge, Cambridge University Press, $330 \mathrm{p}$.

BASTIN A. \& CAILLEUX A., 1941 - Action du vent et du gel au Quaternaire dans la region bordelaise. Bulletin de la Société Géologique de France, série 5, 11, 259-266.

BERTRAN P., ANDRIEUX E., ANTOINE P., COUTARD S., DESCHODT L., GARDËRE P., HERNANDEZ M., LEGENTIL C., LENOBLE A., LIARD M., MERCIER N., MOINE O., SITZIA L. \& VAN VLIET-LANOË B., 2014 - Distribution and chronology of Pleistocene permafrost features in France: database and first results. Boreas, 43 (3), 699-711.

BLACK R.F., 1976 - Periglacial features indicative of permafrost: ice and soil wedges. Quaternary Research, 6 (1), 3-26.

BOCKHEIM J.G., KURZ M.D., SOULE S.A. \& BURKE A., 2009 - Genesis of active sand-filled polygons in lower and central Beacon Valley, Antarctica. Permafrost and Periglacial Processes, 20 (3), 295-308.

BÜDEL J., 1951 - Die klimazonen des Eiszeitalters. Eiszeitalters und Gegenwart, 1, 16-26.

CAILLEUX A., 1948 - Carte des actions périglaciaires quaternaires en France. Bulletin du Service de la Carte Géologique de France, 224, 33-39.

CAILLEUX A., 1956 - Mares, mardelles et pingos. Comptes Rendus, Académie des Sciences, Paris, 242, 1912-1914.

FORTIER D. \& ALLARD M., 2005 - Frost-cracking conditions, Bylot Island, eastern Canadian Arctic archipelago. Permafrost Periglacial Processes, 16 (2), 145-161.

FRIEDMAN J.D., JOHANSSON C.E., OSKARSSON N., SVENSSON H., THORARINSSON S. \& WILLIAMS J.R., 1971 - Observations on Icelandic polygon surfaces and palsa areas, photo interpretation and field studies. Geografiska Annaler, 53A (3-4), 115-145.

GENTY D., COMBOURIEU-NEBOUT N., PEYRON O., BLAMART D., WAINER K., MANSURI F., GHALEB B., ISABELLO L., DORMOY I., VON GRAFENSTEIN U., BONELLI S., LANDAIS A. \& BRAUER A., 2010 - Isotopic characterization of rapid climatic events during OIS3 and OIS4 in Villars Cave stalagmites (SW-France) and correlation with Atlantic and Mediterranean pollen records. Quaternary Science Review, 29 (19-20), 2799-2820.
GOZDZIK J.S., 1986 - Structures de fentes à remplissage primaire sableux du Vistulien en Pologne et leur importance paléogéographique. Biuletyn Peryglacjalny, 31, 71-105.

GOZDZIK J.S., 1994 - Etudes des fentes de gel en Pologne centrale. Biuletyn Peryglacjalny, 33, 49-78.

GULLENTOPS F., 1954 - Contributions à la chronologie du Pléistocène et des formes du relief en Belgique. Mémoire de l'Institut de Géologie de l'Université de Louvain, 18, Louvain, Belgique, $125-252$.

HAESAERTS P. \& VAN VLIET-LANOË B., 1973 - Evolution d'un permafrost fossile dans les limons du dernier glaciaire à Harmignies (Belgique). Bulletin de l'Association Française pour l'Etude du Quaternaire, 10 (3), 151-164.

HUIJZER A.S. \& VANDENBERGHE J., 1998 - Climatic reconstruction of the Weichselian Pleniglacial in northwestern and central Europe. Journal of Quaternary Science, 13 (5), 391-417.

ISARIN R.F.B., HUIJZER A.S. \& VAN HUISSTEDEN J., 1998 - Time-slice oriented multi-proxy database (MPDB) for palaeoclimate reconstruction. In CAPS (Circumpolar Active-Layer Permafrost System) CD-ROM, Version 1.0, National Snow and Ice Data Center. CIRES, University of Colorado.

JETCHICK E. \& ALLARD M., 1990 - Soil wedge polygons in northern Québec: description and paleoclimatic significance. Boreas, 19 (4), 353-365.

JIRAKOVÁ H., HUNEAU F., CELLE-JEANTON H., HRKAL Z. \& LE COUSTUMER P., 2011 - Insights into palaeorecharge conditions for European deep aquifers. Hydrology Journal, 19 (8), 1545-1562.

KAISER K., 1960 - Klimazeugen des periglazialen Dauerfrostbodens in Mittel-und West-Europa. Eiszeitalter und Gegenwart, 11 (1), 121-141.

KOLSTRUP E., 1986 - Reappraisal of the upper Weichselian Periglacial environment from Danish frost wege casts. Palaeogeography, Palaeoclimatology, Palaeoecology, 56 (3-4), 237-249.

LACHENBRUCH A.H., 1962 - Mechanics of thermal contraction cracks and ice-wedge polygons in permafrost. Geological Society of America, Special Paper 70,69 p.

LACHENBRUCH A.H., 1966 - Contraction theory of ice-wedge polygons; a qualitative discussion. In Proceedings, First International Permafrost Conference. National Academy of Science, National Research Council of Canada, Publication 1287, 63-71.

LAUTRIDOU J.P. \& SOMMÉ J., 1981 - L'extension des niveaux repères périglaciaires à grandes fentes de gel de la stratigraphie du Pléistocène récent dans la France du Nord-Ouest. Biuletyn Peryglacjalny, 28, 179-185.

LENOBLE A., BERTRAN P., MERCIER N. \& SITZIA L., 2012 - Le site du Lac Bleu et la question de l'extension du pergélisol en France au Pléistocène supérieur. Quaternaire continental d'Aquitaine : un point sur les travaux récents. Livret-guide de l'excursion AFEQASF 2012, Université de Bordeaux, AFEQ, 107-121.

MAARLEVELD G.C., 1976 - Periglacial phenomena and the mean annual temperature during the Last Glacial Time in the Netherlands. Biuletyn Peryglacjalny, 26, 57-58.

MACKAY J.R., 1993 - Air temperature, snow cover, creep of frozen ground, and the time of ice-wedge cracking, western Arctic coast. Canadian Journal of Earth Sciences, 30 (8), 1720-1729.

MACKAY J.R. \& BURN C.R., 2002 - The first 20 years (1978-1979 to 1998-1999) of ice-wedge growth at the Illisarvik experimental drained lake site, western Arctic coast, Canada. Canadian Journal of Earth Science, 39 (12), 95-111.

MICHEL J.P., 1975 - Périglaciaires des environs de Paris. Biuletyn Peryglacjalny, 24, 259-352.

MILLER R., 2012 - Mapping the expansion of the Northwest Magdalenian. Quaternary International, 272-273, 209-230.

MURTON J.B., 1996 - Morphology and paleoenvironmental significance of Quaternay sand veins, sand wedges and composite wedges, Tuktoyaktuk Coastlands, Western Arctic Canada. Journal of Sedimentary Research, 66 (1), 17-25.

MURTON J.B., 2013 - Permafrost and Periglacial Features. Ice Wedges and Ice-Wedge Casts. In Encyclopedia of Quaternary Science (Second Edition), Elsevier, Amsterdam, 436-451.

MURTON J.B. \& BATEMAN M.D., 2007 - Syngenetic sand veins and anti-syngenetic sand wedges, Tuktoyaktuk Coastlands, western Arctic Canada. Permafrost Periglacial Processes, 18 (1), 33-47.

MURTON J.B., WORSLEY P. \& GOZDZIK J., 2000 - Sand veins and wedges in cold Aeolian environments. Quaternary Science Reviews, 19 (9), 899-922.

NURY D. \& ROUX R.M., 1969 - Présence de cryoturbation et de cailloutis quaternaires à l'ouest de Martigues (Bouches-du-Rhône). Bulletin de l'Association Française pour l'Etude du Quaternaire, 6 (2), 139-143. 
PEWÉ T.L., 1959 - Sand-wedge polygons (tessellations) in the McMurdo Sound Region, Antarctica a progress report. American Journal of Science, 257, 545-552.

PÉWÉ T.L., 1966 - Palaeoclimatic significance of fossil ice wedges Biuletyn Peryglacjalny, 5, 65-72.

POSER H., 1948 - Boden-und Klimaverhältnisse im Mittle-und Westeuropa während der Würmeiszeit. Erdkunde, 2, 53-68.

RENSSEN H. \& VANDENBERGHE J., 2003 - Investigation of the relationship between permafrost distribution in NW Europe and extensive winter sea-ice cover in the North Atlantic Ocean during the cold phases of the Last Glaciation. Quaternary Science Reviews, $22(2 / 4), 209-223$.

ROMANOVSKIJ N.N., 1973 - Regularities in formation of frostfissures and development of frost-fissure polygons. Biuletyn Peryglacjalny, 23, 237-277.

ROMANOVSKIJ N.N., 1976 - The scheme of correlation of polygonal wedge structures. Biuletyn Peryglacjalny, 26, 287-294.

ROMANOVSKIJ N.N., 1985 - Distribution of recently active ice and soil wedges in the USSR. In M. Church, \& O. Slaymaker, (eds.), Field and Theory - Lectures in Geocryology. University of British Columbia Press, Vancouver, 154-165.

TALLAVAARA M., LUOTO M., KORHONEN N., JÄRVINEN H. \& SEPPÄ H., 2015 - Human population dynamics in Europe over the Last Glacial Maximum. PNAS, 112 (27), 8232-8237.

TRICART J., 1963 - Géomorphologie des régions froides. Presse universitaire de France, Paris, 389 p.

TRICART J. \& CAILLEUX A., 1967 - Le modelé des régions péri glaciaires. SEDES, Paris, $512 \mathrm{p}$.

VANDENBERGHE J., 1983 - Ice-wedge casts and involutions as permafrost indicators and their stratigraphic position in the Weichselian. Proceedings of the 4th International Conference on Permafrost. Fairbanks, Alaska, 1, 1298-1302.

VANDENBERGHE J. \& PISSART A., 1993 - Permafrost changes in Europe during the last glacial. Permafrost and Periglacial Process, $4(2), 121-135$.

VANDENBERGHE J., FRENCH J., GORBUNOV A., MARCHENKO S, VELICHKO A.A., JIN H., CUI Z, ZHANG T. \& WAN W., 2014 - The Last permafrost Maximum (LPM) map of the Northern Hemisphere: permafrost extent and mean annual air temperatures, 25-17 ka. Boreas, 43, 652-666.
VELICHKO A.A., 1982 - Palaeogeography of Europe during the Last One Hundred Thousand Years. Nauka, Moscow, $156 \mathrm{p}$

VAN VLIET-LANOË B., 1989 - Dynamics and extent of the Weichselian permafrost in western Europe (substage 5e to stage 1). Quaternary International, 3-4, 109-113.

VAN VLIET-LANOË B., 1996 - Relations entre la contraction thermique des sols en Europe du Nord-Ouest et la dynamique de l'inlandsis weichselien. Comptes-rendus de l'Académie des Science Paris, 322 (série IIa), 461-468.

VAN VLIET-LANOË B., 2005 - Deformation in the active layer related with ice/soil wedge growth and decay in present day Arctic. Paleoclimatic implications. Annales de la Société Géologique du Nord, 13, 81-95.

VAN VLIET-LANOË B. \& HALLÉGOUËT B., 2001 - European permafrost at the LGM and at its maximal extent. The geologica approach. In R. Paepe, \& V. Melnikov (eds.), Permafrost Response on Economic Development, Environmental Security and Natural Resources. Kluwer Academic Publishers, Dordrecht, 195-213.

VAN VLIET-LANOË B., \& LANGOHR R., 1981 - Correlation between fragipans and permafrost with special reference to Weische silty deposits in Belgium and Northern France. Catena, 8, 137-154.

WASHBURN A.L., 1979 - Geocryology. A Survey of Periglacial Processes and Environments. Edward Arnold, London, 406 p.

WASHBURN A.L., SMITH D. \& GODDARD R., 1963 - Frost cracking in a Middle Latitude climate. Biuletyn Peryglacjalny, 12, 175-189.

WILLIAMS R.B.G., 1964 - Fossil patterned ground in eastern England. Biuletyn Peryglacjalny, 22, 337-349.

WILLIAMS R.B.G., 1968 - Periglacial climate and its relation to landforms: a study of southern and eastern England during the Last Glacial Period. PhD Thesis, University of Cambridge.

YVARD J.C., 1968 - Fentes de gel périglaciaire de la région de Tours. Bulletin de l'Association Française pour l'Etude du Quaternaire, 3 , 175-179. 